Pakistan Journal of Humanities and Social Sciences

January - March 2018, Volume 6, No. 1, Pages 144 - 159

\title{
Dynamics of ESL Writing Performance: A Theoretical Framework
}

\author{
Kiran Shehzadi ${ }^{1}$, Hariharan a/I N. Krishnasamy ${ }^{2}$ \\ ${ }^{1}$ Ph.D. Scholar, School of Languages, Civilization and Philosophy, College of Arts and \\ Sciences, University Utara Malaysia \\ ${ }^{2}$ School of Languages, Civilization and Philosophy, College of Arts and Sciences, University \\ Utara Malaysia \\ Email: kiranshehzadilodhi@gmail.com
}

\begin{abstract}
The objective of this research is to investigate the dynamics of English as a Second Language (here onwards, ESL) writing and to present a theoretical framework for empirical testing the proposed factors affecting ESL writing. The analysis of literature showed that ESL writing anxiety and the use of first/native language (L1) are among the key factors that significantly affect ESL writing performance of students at various academic levels. Additionally, it is also revealed that ESL writing self-efficacy is a factor that is related to ESL writing performance as well as ESL writing anxiety and the interference of the first language in ESL writing. The interference model, the linguistic interdependence model, common underlying proficiency hypothesis and the self-efficacy theory are the theories that theoretically support such empirical investigation. Therefore, it is proposed that ESL writing self-efficacy should be examined as a moderating variable in the relationship of ESL writing anxiety and the use of L1 with ESL writing performance in future research.
\end{abstract}

Keywords: ESL writing performance, native language, ESL writing anxiety, ESL writing self-efficacy.

\section{Introduction}

Due to colonialism and globalization, English has become the dominant language in the world (Rassool, 2013). English plays a number of crucial roles in developing countries, especially those which were British colonies in the past, including Pakistan, India and Bangladesh (Mansoor, 2003; Mohanty, Panda, \& Pal, 2010; Rahman, 1999; Rahman, 2005; Tickoo, 1996). In Pakistan, English is one of the official languages, thus a pre-requisite for most professional jobs (Rahman, 2005). It is also the language of education, especially higher education. Hence, English is considered a source of self-improvement and career success as it provides access to the local and global resources (Mansoor, 2003; Norton \& Kamal, 2003; Rahman, 2002, 2005). 
In academics, written assignments are normally a requirement because of its importance in the examination process. However, it has long been claimed that writing in the second language is a challenging skill to acquire, thereby, producing a feeling of fear among the second language (L2) learners (Gupta, 1998). The use of English in education and English medium instruction in developing countries is a source of failure for many people (Coleman, 2010; Manan, David, \& Dumanig, 2015; Rahman, 2004). Coleman (2010) challenges the usefulness of English in daily life in Pakistan. He stated that more often the English language is considered as a formal prerequisite for entering the civil services or other forms of jobs; therefore, English is playing a gate keeping role in Pakistan. As a result, the major function of English teaching in Pakistani schools is to prepare students for different examinations, because passing examinations in the English language opens the doors for employment. Therefore, this research intends to investigate the issue of ESL writing performance and proposes a theoretical model that may explain the differences in ESL writing performance of students.

\section{ESL Writing Performance and ESL Writing Anxiety}

Writing, one of the four basic language skills, is a means of narrating feelings, thoughts, desires and events using specific symbols in accordance with certain rules (Berk \& Ünal, 2017). Sever (2004) referred writing action as expressing one's senses, thoughts, plans and experiences through writing. Since writing is intertwined with mental processes, it contributes to the development of many skills. It helps to widen students' thoughts, organize their knowledge, use language, enrich their knowledge accumulation and develop their mental dictionaries (Berk \& Ünal, 2017). In addition, it makes easier to examine what is being thought by putting them on paper.

For second and foreign language learners, writing is a demanding activity because this skill helps students to perform better in course work and examinations especially, at the university level. An excellent expertise in English writing is crucial to enhance university students' writing performance, thus academic success. Regardless of its significance, many students consider English writing as difficult, challenging, and frustrating because their writing is generally poor in terms of vocabulary, organization, content, and the use of linguistic features (Liao \& Wong, 2010). The students often do writing only in exams and this link between examination and writing may produce the feeling of fear in them in the process of writing (Shang, 2013). 
The poor performance in ESL writing is attributed to a number of factors. Studies have shown that when students do not enjoy learning the target language, they will perform negatively in the language (Andrade \& Williams, 2009; Gregersen \& Horwitz, 2002; Tuncay \& Uzunboylu, 2010). Anxiety is one of the key factors that makes the process of learning a second language difficult for many language learners (Luo, 2018). Although its effects may vary from one individual to another, it plays an important role in determining the performance of a language learner in a target language, in this case, the English language.

Second language learning is a process in which emotional and particularly psychological factors play a dominant role. Majority of ESL students acknowledge second language writing as a difficult task because writing is an affective and cognitive activity as well (Cheng, 2002; Lee, 2005). Since 1970s, the effect of anxiety on second or foreign language learning has been investigated (Liu, 2006), and attempts have been made by the researchers to identify and develop the measurement of anxiety in second language classrooms for many years since students are usually anxious about their writing ability for the purpose of successful communication (Schmidt, 2004). Foreign language anxiety is a distinct type of anxiety specifically related to foreign language learning (Horwitz, Horwitz and Cope, 1986; MacIntyre \& Gardner, 1991). They defined anxiety as "a distinct complex of self-perceptions, feelings and behaviours related to classroom language learning process" ( $p$. 127). In addition, they claimed that language courses often provoke anxiety. A number of researches have revealed that students who utilise skills such as, speaking and writing, experience a substantial amount of anxiety in their learning process (Hilleson, 1996; Jun Zhang, 2001).

As a productive skill, writing has also been examined by many researchers in terms of anxiety. Cheng, Horwitz and Schallert (1999) have shown that writing anxiety and foreign language anxiety are two related but independent constructs, while second language writing anxiety is a language-skill-specific anxiety. Due to its unique inherent nature, there have been several studies focusing on writing anxiety (Atay \& Kurt, 2006; Cheng, 2002; Erkan \& Saban, 2011). According to Hassan (2001), foreign language writing anxiety involves avoiding writing and its evaluation. Cheng (2004b, p. 319), however, maintained that "L2 writing anxiety is a relatively stable anxiety disposition associated with L2 writing, which involves a variety of dysfunctional thoughts, increased physiological arousal, and maladaptive behaviours". As writing anxiety may significantly affect writing performance of learners (F 
Pajares \& Johnson, 1994; Smith, 1984), second language writing anxiety has gained more significance as a field of study.

Writing anxiety is a common problem affecting ESL learners' writing performance. As writing skill is considered the most difficult skill that needs to be acquired by ESL learners, it is pertinent to manage the anxiety level to encourage learners to write. The facilitative effect of anxiety is important in enhancing writing skills, particularly among low proficiency students (Rahim, Jaganathan, Sepora, \& Mahadi, 2016). Studies such as Scovel (1978) and Hassan (2001) have shown that students' ESL writing anxiety is positively related to ESL writing performance.

Moreover, it is found that high anxious learners obtain lower scores in standardized writing tests (Shang, 2013) and their written essays receive lower grades (Ying \& Krashen, 2002). Numerous studies such as Daly, (1978), Cheng (2002), Andrade and Williams (2009), Tuncay and Uzunboylu (2010), Rezaei, Jafari and Younas (2014) also found that ESL writing performance is negatively affected by ESL writing anxiety supporting the claim made by Horwitz et al. (1986) that three sources of foreign language anxiety, namely; fear of negative evaluation, test anxiety and communication anxiety may adversely influence ESL/EFL writing performance. The level of writing anxiety even increases among students if the contribution of written assignments is substantially high to the final grades of the course (Schmidt, 2004). The students suffering from writing anxiety may experience increased anxiety if they are asked to write, and their written work, behaviours and attitudes reflect this anxiety. Moreover, such students experience more difficulty in the process of ideas creation for writing, production of shorter words, and with the usage of grammar and mechanics in written assignments (Reeves, 1997; Shang, 2013). Therefore, ESL writing anxiety can be a hindrance to enhancing ESL writing performance.

\section{Use of L1 and ESL Performance}

Similarly, using the first language of students in the second language (L2) classrooms has been a contentious issue. One camp strongly believes that L2 should be exclusively used (Cook, 2001; Howatt, 1984). Those who support the use of L1 do so mainly for the following reasons: lowering students' memory constraints (Harbord, 1992; Kern, 1994); facilitating communication (Pennington, 1995); lowering their affective filters (Meyer, 2008); for task management (Swain \& Lapkin, 2001); and as a means of social equality (Adendorff, 1996; Auerbach, 1993). Previously, in the Indian context, the role of L1 as a resource to learn L2 (English) was acknowledged and practised (Sastri, 1970; Tickoo, 2003). 
Theoretical support for the idea that the L1 can be used as a scaffolding device for the L2 came only in 1986, with Jim Cummins' concept of a 'common underlying proficiency' (CUP). This term refers to a set of higher order academic skills (e.g., reading, inferential skills, summarizing skills), and an implicit metalinguistic knowledge that is required for academic success. These skills, Cummins argued, once acquired through one language, are open for transfer. So, they can be drawn upon from the stronger to the weaker language.

The ESL teachers have given emphasis on the need for thinking and writing in English as completely as possible for ESL writers. This is due to the belief that if the work is done by the ESL writers in their native language, it will hinder the acquisition of the second language, thereby, interfering in the process of the generation of second language structures, because of the transfer of vocabulary and structures from the native language in an inappropriate manner (Friedlander, 1990). However, a voluminous literature has shown that, regardless of a language prescription, the strategies and skills from native language, whether deficient or good, are transferred to the second language. For example, Mohan and Lo (1985) cited a study conducted by Das who highlighted that students lacking in first or native language strategies show a similar pattern in the process of writing in their second language (English). They contended that this deficiency is developmental in nature which means that students cannot have suitable strategies to transfer in the second language until they do not develop good strategies for writing in their native language. The study of Edelsky (1982) on writing in a bilingual program of first, second, and third graders also found the evidence of the transfer of writing knowledge across two languages. The findings of her research reveal that writers utilise the knowledge and strategies of their first language to write in and support their second language.

Likewise, Jones and Tetroe (1987) in another research study, examined the process of texts generation by ESL writers in both their native and second languages. They also reached the same conclusion as Edelsky (1982) that ESL writers transfer their writing skills, both weak and good, from their first language to the second language. Moreover, they noted that the failure of weaker writers in using writing strategies in their second language was due to their failure to utilise these writing strategies in their first language. Alternatively, strategies never acquired in the first language cannot be transferred to the writing in the second language. In contrast, Silva (1986) argued that individuals have effective first language strategies to transfer to their second language writing context; the first language and 
second language composing processes of individuals displayed similar high-level goal structures and problem representations.

The advantages of using L1 for L2 are manifold and have been widely researched. One such positive impact has been found in using L1 writing and academic skills to develop L2 writing skills. A common belief is that L2 proficiency is a primary determinant of success in acquiring L2 academic skills such as writing skill. But studies that have tested the Cumminsian transfer hypothesis have shown that L1 writing skills can be a determinant of success in L2 writing such as Lanauze and Snow (1989) and Woodall (2002) among others. Likewise, Friedlander, (1990) found that L1 use in planning ESL writing has a positive impact on the L2 writing quality of adult students. Similarly, Mukhopadhyay (2015) also tested the Cummins' hypothesis and found L1 as a determinant of enhanced ESL writing performance.

\section{ESL Writing Self-Efficacy and ESL Writing Performance}

Another significant factor affecting language learning is self-efficacy. The component of self-efficacy in Bandura's social cognitive theory designates how selfperceptions regarding the capabilities to perform particular tasks strongly affect individuals' engagement in doing and successfully completing the task (Klassen, 2002). According to the self-efficacy theory, those who do not believe in their skills and capacities avoid engaging in tasks which require those skills, while people who believe in their abilities do not give up in the face of difficulties (Nazzal, 2008). As argued by Bandura (1986, p. 425), "if self-efficacy is lacking, people tend to behave ineffectually, even though they know what to do". As far as writing self-efficacy beliefs are concerned, Pajares (2003) argued that if learners have positive beliefs about their writing skills, they feel less anxious while writing, since those positive beliefs lead to increased writing interest, continuous efforts and enhanced persistence when difficulties are encountered.

Particularly during the past two decades, researchers focused on self-efficacy as a significant predictor in explaining students' learning and motivation (Zimmerman, 2000). As one of those researchers, Bandura (1997) asserted that academic performance is strongly affected by academic self-beliefs. Thus, if learners believe they have the ability to write, their writing performance will increase (McCarthy, Meier, \& Rinderer, 1985). There have been numerous studies which explored the relationship between second language writing selfefficacy beliefs and second language writing anxiety. For instance, Hassan's (2001) study showed a negative correlation between these two variables. Also, Cheng (2004b) contended 
that there exists a significant negative correlation between ESL writing anxiety and second language writing self-efficacy beliefs. Moreover, Trylong (1987) claimed that anxiety levels of students and their self-beliefs about language proficiency are negatively associated (as cited in Cubukcu (2008)). Similarly, Daly and Wilson (1983), Onwuegbuzie (1999), and Pajares and Johnson (1994) found that writing anxiety levels are indirectly associated to individuals' self-efficacy beliefs (as cited in Erkan and Saban (2011)).

Similarly, Qashoa (2014) indicated that English language anxiety can be reduced by enhancing self-confidence of ESL students generally, and in writing classes particularly. Likewise, it is argued that the effect of writing self-efficacy on writing performance is higher as compared to the effect of writing anxiety (Frank Pajares, 2003; Frank Pajares \& Johnson, 1998). It is claimed that enhanced writing self-efficacy decreases levels of writing anxiety among students, thereby, enhancing their performance in writing (Martinez, Kock, \& Cass, 2011). In a more recent study, Latif (2015) revealed that ESL writing anxiety is strongly related to low levels of writing as well as general language self-efficacy. Similarly, Wu, Lowyck, Sercu and Elen (2013) investigated the effect of self-efficacy beliefs on ESL performance and could not find a direct relationship between self-efficacy beliefs of individuals and their ESL performance.

\section{Theoretical Framework}

Based on the above discussion, it can be stated that ESL writing anxiety, the use of first or native language are the major factors that significantly affect ESL writing performance. In this regards, inconsistency has been found in the findings of various research studies where the debilitative, as well as facilitative effect of ESL writing anxiety on ESL writing performance, has been found. Similarly, the use of L1 in composing L2 produced positive as well as negative results in terms of ESL writing performance. Therefore, it is suggested to use a moderating variable that may explain these inconsistencies. Based on the discussion carried in this paper, ESL writing self-efficacy is considered an important variable that can moderate the relationship of ESL writing anxiety and the use of L1 with ESL writing performance. Hence, the following conceptual framework is proposed to investigate the dynamics of ESL writing performance. 


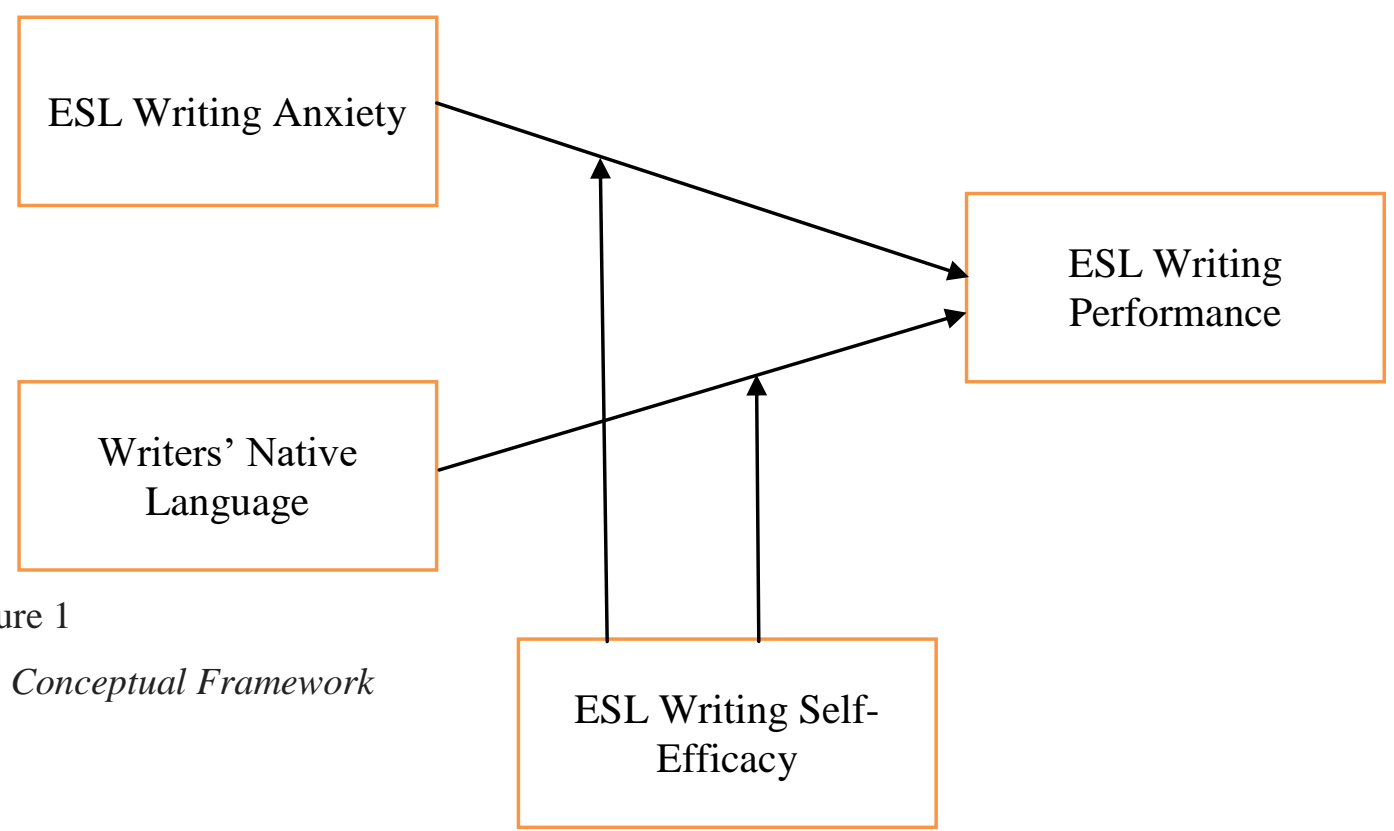

The proposed conceptual framework presented in Figure 1 can be well supported with the Interference model, the Linguistic Interdependence hypothesis, the Common Underlying Proficiency (CUP) hypothesis and the Self-Efficacy theory. These theories are elaborated as follows:

\section{A. The Interference Model}

The relationship between ESL writing anxiety and ESL writing performance can be explained using the 'Interference Model'. Before explaining the interference model, a brief look at the deficit model clarifies the need for developing the interference model. The deficit model states that poor performance of anxious students is because of their deficiency in acquiring the language skill. However, Horwitz (2000) disagreed with the assertion of the deficit model by arguing that anxiety is a strong factor which can interfere in the process of learning, and the deficit hypothesis may be applied in some of the situations of language anxiety, but not all.

According to the interference model proposed by Horwitz (2000), the low performance of anxious students is because of challenges and difficulties in the process of retrieving information and not due to the deficiency in learning or inadequate subject knowledge. Most research on anxiety has used the interference model as a base, and not on the deficit model (Kara, 2013; Musch \& Broder, 1999). The argument provided by Horwitz 
(1986) is that anxiety and self-consciousness of the language learner are produced by the mismatch between mature thoughts and immature foreign or second language proficiency. The dysphonic effect of anxiety may aggravate in the situations of test or being observed rather than just an approach of communication.

\section{B. The Linguistic Interdependence Hypothesis}

The relationship between writers' native language (L1) and ESL writing performance can be explained using 'Linguistic Interdependence Hypothesis'. Cummins (1979) had explained second language acquisition using this hypothesis. In this hypothesis, Cummins (1979) proposed that "only if a learner has sufficient exposure to L2 and motivation to learn it, language skills will transfer from the first language to the second language". This hypothesis describes the relationship between native language and second language learning and indicates how native language affects the learning of a second language. In other words, despite differences in first and second language, they are dependent upon each other. This hypothesis states that certain L1 linguistic skills and knowledge can be positively transferred during the acquisition process of L2, and this transfer of skills occurs automatically (Cummins, 1979).

\section{The Common Underlying Proficiency Hypothesis}

In addition to the Linguistic Interdependence hypothesis, the Common underlying proficiency (CUP) hypothesis proposed by Cummins (2000) also provides the foundation for developing both the first and second language. The term CUP has also been used to refer to the cognitive and academic proficiency that affects performance in both languages (Cummins, 2000). The relationship between the first and the second language literacy skills suggests that effective skill developments in the native language can provide a conceptual base for longterm growth in second language literacy skills as well as performance. As Cummins (2000) asserted that "conceptual knowledge developed in L1 is used as an input in the L2 comprehension." He stated that skills learnt by a student in any language can be transferred in the process of learning a second language.

\section{The Self-Efficacy Theory}

Self-efficacy beliefs are considered as an imperative aspect of human behaviour and motivation, and it affects the actions, which in turn, affects an individual's life. Self-efficacy and anxiety seem intuitively associated. People who feel ineffective in dealing with life's inevitable problems and challenges cannot help but be anxious at the thought of how they will manage these challenges when they arise. People with higher self-efficacy handle anxiety 
differently than those with low self-efficacy (Ghaderi \& Salehi, 2011). As ESL writing anxiety negatively affects ESL writing performance, students with higher ESL self-efficacy handle their anxiety, thereby, enhancing their ESL writing performance. Self-efficacy has often been linked to students' writing performance. More so than any other element within the cognitive-affective domain, self-efficacy beliefs have proven to be predictive of performance outcomes in writing (Frank Pajares, 2003; Schunk, 2003). In order to enhance language performance in any of the four skills, Nitko (2001) encourages teachers to be well aware of the language learning anxiety, which negatively affects the performances of students (Supon, 2004). Nitko (2001) argued that the wrong self-perceptions of students about their capabilities or lower self-efficacy enhance anxiety, which in turn, reduces the performance of students.

\section{Conclusion and Recommendations for Future Research}

The present research was focused on the factors affecting ESL writing performance. The discussion presented earlier has shown that ESL writing anxiety and the use of L1 are important predictors of ESL writing performance. Moreover, these relationships are found positive as well as negative in existing body of literature which calls for further research in order to investigate the reason of such mixed findings. These evidence of mixed findings calls for further research by introducing a possible moderating variable such as proposed earlier ESL writing self-efficacy among others. Therefore, it is recommended for future researchers to examine the aforementioned relationships by including some moderating variables. 


\section{References}

Adendorff, R. (1996). The functions of code switching among high school teachers and students in KwaZulu and implications for teacher education. In Voices from the Language Classroom: Qualitative Research in Second Language Education (pp. 388-406).

Andrade, M., \& Williams, K. (2009). Foreign language learning anxiety in Japanese EFL university classes: Physical, emotional, expressive, and verbal reactions. Sophia Junior College Faculty Journal, 29(1), 1-24.

Atay, D., \& Kurt, G. (2006). Prospective teachers and L2 writing anxiety. Asian EFL Journal, $8(4), 100-118$.

Auerbach, E. R. (1993). Reexamining English Only in the ESL Classroom. TESOL Quarterly, 27(1), 9.

Bandura, A. (1986). The explanatory and predictive scope of self-efficacy theory. Journal of Social and Clinical Psychology, 4(3), 359-373.

Bandura, A. (1997). Self-efficacy: The exercise of control. New York: Freeman.

Berk, R., \& Ünal, E. (2017). Comparison of Writing Anxiety and Writing Dispositions of Sixth, Seventh and Eighth Grade Students. International Journal of Instruction, $10(1), 237-254$.

Cheng, Y. (2002). Factors Associated with Foreign Language Writing Anxiety. Foreign Language Annals, 35(6), 647-656.

Cheng, Y. (2004). EFL students' writing anxiety: Sources and implications. English Teaching \& Learning, 29(2), 41-62.

Cheng, Y., Horwitz, E. K., \& Schallert, D. L. (1999). Language Anxiety: Differentiating Writing and Speaking Components. Language Learning, 49(3), 417-446.

Coleman, H. (2010). The English language in development. London: The British Council.

Cook, V. (2001). Using the First Language in the Classroom. Canadian Modern Language Review, 57(3), 402-423.

Cubukcu, F. (2008). A Study on the Correlation between Self Efficacy and Foreign Language Learning Anxiety. Journal of Theory and Practice in Education, 4(1), 148-158.

Cummins, J. (1979). Linguistic interdependence and the educational development of bilingual children. Review of Educational Research, 49(2), 222-251.

Cummins, J. (2000). Language, power, and pedagogy: Bilingual children in the crossfire. Clevedon, UK: Multilingual Matters. 
Pakistan Journal of Humanities and Social Sciences, 6(1), 2018

Daly, J. A. (1978). Writing Apprehension and Writing Competency. The Journal of Educational Research, 72(1), 10-14.

Edelsky, C. (1982). Writing in A Bilingual Program: The Relation of L1 and L2 Texts. TESOL Quarterly, 16(2), 211.

Erkan, Y., \& Saban, A. (2011). Writing performance relative to writing apprehension, selfefficacy in writing, and attitudes towards writing: A correlational study in Turkish tertiary-level EFL. The Asian EFL Journal Quarterly, 13(1), 163-191.

Friedlander, A. (1990). Composing in English: Effects of a first language on writing in English as a second language. In Second language writing: Research insights for the Classroom (pp. 109-125). New York: Cambridge University Press.

Ghaderi, A., \& Salehi, M. (2011). A Study of the Level of Self-efficacy, Depression, and Anxiety between Accounting and Management Students: Iranian Evidence. World Applied Sciences Journal, 12(8), 1299-1306.

Gregersen, T., \& Horwitz, E. K. (2002). Language Learning and Perfectionism: Anxious and Non-Anxious Language Learners' Reactions to Their Own Oral Performance. The Modern Language Journal, 86(4), 562-570.

Gupta, R. (1998). Writing with a different tool. In Computers and Language Learning. Singapore: SEAMEO Regional Language Center.

Harbord, J. (1992). The use of the mother tongue in the classroom. ELT Journal, 46(4), 350355.

Hassan, B. (2001). The Relationship of Writing Apprehension and Self-Esteem to the Writing Quality and Quantity of EFL University Students. Mansoura Faculty of Education Journal, 39, 1-36.

Hilleson, M. (1996). I want to talk with them, but I don't want them to hear": An introspective study of second language anxiety in an English-medium school. In Voices from the language classroom (pp. 248-282). Cambridge: Cambridge University Press.

Horwitz, E. K. (1986). Preliminary Evidence for the Reliability and Validity of a Foreign Language Anxiety Scale. TESOL Quarterly, 20(3), 559.

Horwitz, E. K. (2000). It Ain't Over 'til It's Over: On Foreign Language Anxiety, First Language Deficits, and the Confounding of Variables. The Modern Language Journal, 84(2), 256-259.

Horwitz, E. K., Horwitz, M. B., \& Cope, J. (1986). Foreign Language Classroom Anxiety. 
The Modern Language Journal, 70(2), 125-132.

Howatt, A. R. P. (1984). A History of English Language Teaching. London: Oxford University Press.

Hult, F. M. (2012). English as a Transcultural Language in Swedish Policy and Practice. TESOL Quarterly, 46(2), 230-257.

Jones, S., \& Tetroe, J. (1987). Composing in a second language. In Writing in Real Time: Modelling Production Processes (pp. 34-57). New York: Longman.

Jun Zhang, L. (2001). Awareness in Reading: EFL Students' Metacognitive Knowledge of Reading Strategies in an Acquisition-poor Environment. Language Awareness, 10(4), 268-288.

Kara, S. (2013). Writing Anxiety: A Case study on students' reasons for anxiety in writing. Anadolu Journal of Educational Sciences International, 3(1), 103-111.

Kern, R. (1994). The role of mental translation in second language reading. Studies in Second Language Acquisition, 16(441), 461.

Klassen, R. (2002). Writing in early adolescence: A review of the role of self-efficacy beliefs. Educational Psychology Review, 14(2), 173-203.

Lanauze, M., \& Snow, C. (1989). The relation between first-and second-language writing skills: Evidence from Puerto Rican elementary school children in bilingual programs. Linguistics and Education, 1(4), 323-339.

Latif, M. A. (2015). Sources of L2 writing apprehension: a study of Egyptian university students. Journal of Research in Reading, 38(2), 194-212.

Lee, S. (2005). Facilitating and Inhibiting Factors in English as a Foreign Language Writing Performance: A Model Testing With Structural Equation Modeling. Language Learning, 55(2), 335-374.

Liao, M., \& Wong, C. (2010). Effects of dialogue journals on L2 students' writing fluency, reflections, anxiety, and motivation. Reflections on English Language Teaching, 9(2), $139-170$.

Liu, M. (2006). Anxiety in Chinese EFL students at different proficiency levels. System, 34(3), 301-316.

Luo, H. (2018). Predictors of Foreign Language Anxiety: A Study of College-Level L2 Learners of Chinese. Chinese Journal of Applied Linguistics, 41(1), 3-24.

MacIntyre, P. D., \& Gardner, R. C. (1991). Language Anxiety: Its Relationship to Other Anxieties and to Processing in Native and Second Languages*. Language Learning, 
Pakistan Journal of Humanities and Social Sciences, 6(1), 2018

41(4), 513-534.

Manan, S. A., David, M. K., \& Dumanig, F. P. (2015). Disjunction between language policy and children's sociocultural ecology - an analysis of English-medium education policy in Pakistan. Language and Education, 29(5), 453-473.

Mansoor, S. (2003). Language Planning in Higher Education Issues of Access and Equity. Lahore Journal of Economics, 8(2), 17-42.

Martinez, C. T., Kock, N., \& Cass, J. (2011). Pain and Pleasure in Short Essay Writing: Factors Predicting University Students' Writing Anxiety and Writing Self-Efficacy. Journal of Adolescent \& Adult Literacy, 54(5), 351-360.

McCarthy, P., Meier, S., \& Rinderer, R. (1985). Self-efficacy and writing: A different view of self-evaluation. College Composition and Communication.

Meyer, H. (2008). The pedagogical implications of L1 use in the L2 classroom. Maebashi Kyoai Gakuen College Ronsyu, 8, 147-160.

Mohan, B. A., \& Lo, W. A.-Y. (1985). Academic Writing and Chinese Students: Transfer and Developmental Factors. TESOL Quarterly, 19(3), 515.

Mukhopadhyay, L. (2015). USING L1 KNOWLEDGE TO ENHANCE L2 WRITING PERFORMANCE. The EFL Journal, 6(1), 13-28.

Musch, J., \& Broder, A. (1999). Test anxiety versus academic skills: A comparison of two alternative models for predicting performance in a statistics exam. British Journal of Educational Psychology, 69(1), 105-116.

Nazzal, N. (2008). The relationship of second language writing apprehension, writing selfefficacy beliefs, and the writing performance of EFL AUB students. American University of Beirut, Lebanon.

Norton, B., \& Kamal, F. (2003). The Imagined Communities of English Language Learners in a Pakistani School. Journal of Language, Identity \& Education, 2(4), 301-317.

Onwuegbuzie, A. J. (1999). Writing Apprehension among Graduate Students: Its Relationship to Self-Perceptions. Psychological Reports, 84(3), 1034-1039.

Pajares, F. (2003). SELF-EFFICACY BELIEFS, MOTIVATION, AND ACHIEVEMENT IN WRITING: A REVIEW OF THE LITERATURE. Reading \& Writing Quarterly, 19(2), 139-158.

Pajares, F., \& Johnson, M. (1994). Confidence and competence in writing: The role of selfefficacy, outcome expectancy, and apprehension. Research in the Teaching of English, 28(3), 313-331. 
Pajares, F., \& Johnson, M. J. (1998). Self-efficacy beliefs and the writing performance of entering high school students. Psychology in the Schools, 33(2), 163-175.

Pennington, M. C. (1995). Pattern and Variation in Use of Two Languages in the Hong Kong Secondary English Class. RELC Journal, 26(2), 80-105.

Qashoa, S. H. H. (2014). English Writing Anxiety: Alleviating Strategies. Procedia - Social and Behavioral Sciences, 136, 59-65.

Rahim, S. A., Jaganathan, P., Sepora, T., \& Mahadi, T. (2016). An Investigation on the Effects of Writing Anxiety on Readiness of Writing among Low Proficiency Undergraduates. International Journal of Language Education and Applied Linguistics, 05, 11-20.

Rahman, A. (1999). English language teaching in Bangladesh: Didactics on the pragmatics of a language teaching policy. In In Collected papers of the international conference on national and regional issues in English language teaching: International perspectives. Dhaka: British Council.

Rahman, T. (2002). Language, ideology and power: Language learning among the Muslims of Pakistan and North India. Karachi: Oxford University Press.

Rahman, T. (2004). Denizens of alien worlds: A survey of students and teachers at Pakistan's Urdu and English language-medium schools, and madrassas. Contemporary South Asia, 13(3), 307-326.

Rahman, T. (2005). The Muslim Response to English in South Asia: With Special Reference to Inequality, Intolerance, and Militancy in Pakistan. Journal of Language, Identity \& Education, 4(2), 119-135.

Rassool, N. (2013). The political economy of English language and development: English vs. national and local languages in developing countries. In English and development: Policy, pedagogy and globalization (pp. 45-67). Bristol: Multilingual Matters.

Reeves, L. (1997). Minimizing writing apprehension in the learner-centered classroom. The English Journal, 86(6), 38-45.

Rezaei, M., Jafari, S., \& Younas, M. (2014). Iranian EFL students' writing anxiety: levels, causes and implications. English for Specific Purposes World, 15(42), 1-10.

Sastri, K. (1970). A comprehensive history of India. Orient Longamns.

Schmidt, L. (2004). Psychometric evaluation of the writing-to-learn attitude survey. Journal of Nursing Education, 43(10), 458-465.

Schunk, D. (2003). Self-efficacy for reading and writing: Influence of modeling, goal setting, 
Pakistan Journal of Humanities and Social Sciences, 6(1), 2018

and self-evaluation. Reading \&Writing Quarterly, 19, 159-172.

Scovel, T. (1978). The effect of affect on foreign language learning: A review of the anxiety research. Language Learning, 28(1), 129-142.

Sever, S. (2004). Turkce Ogretimi ve Tam Ogrenme (4. baski). Ankara: Am Yayincilik.

Shang, H. (2013). Factors Associated With English As a Foreign Language University Students Writing Anxiety. International Journal of English Language Teaching, 1(1), $1-12$.

Silva, M. M. (1986). First and second language composing processes: A case study. In A paper presented at the 20th Annual TESOL Convention.

Smith, M. (1984). Reducing Writing Apprehension. Illinois: ERIC Clerainghouse on Reading and Communicaiton Skills.

Swain, M., \& Lapkin, S. (2001). Focus on form through collaborative dialogue: Exploring task effects. In Researching Pedagogic Tasks (pp. 99-118). London: Routledge.

Sy-Ying, L., \& Krashen, S. (2002). Predictors of success in writing in English as a foreign language: Reading, revision behavior, apprehension, and writing. College Student Journal, 36(4), 532-543.

Tickoo, M. (1996). Fifty years of English in Singapore: All gains,(a) few losses? In Post Imperial English: Status Change in Former British and American Colonies, 19401990. Berlin: De Gruyter.

Tickoo, M. (2003). Teaching and Learning English: A Sourcebook for Tearchers and Teacher-trainers. New Delhi: Orient Longman.

Trylong, V. (1987). Aptitude, attitudes, and anxiety: A study of their relationships to achievement in the foreign language classroom. Purdue University.

Tuncay, N., \& Uzunboylu, H. (2010). Trend of Distance Education in the last three Decades. World Journal on Educational Technology, 2(1), 55-67.

Woodall, B. (2002). Language-switching: Using the first language while writing in a second language. Journal of Second Language Writing, 11(1), 7-28.

Wu, X., Lowyck, J., Sercu, L., \& Elen, J. (2013). Task complexity, student perceptions of vocabulary learning in EFL, and task performance. British Journal of Educational, 83(1), 160-181.

Zimmerman, B. J. (2000). Self-Efficacy: An Essential Motive to Learn. Contemporary Educational Psychology, 25(1), 82-91. 